\title{
Genetic Relationship of Minerals and Carbonate Units of Stratigraphy Sequence in the Ahmadabad Deposit (NE of Bafq) Using Data Related to Rare Earth Elements
}

\author{
Sara Amani Lari ${ }^{1,2 *}$, Iraj Rassa ${ }^{3}$, Ali Amiri ${ }^{4}$ \\ ${ }^{1}$ Department of Geology, College of Basic Science, Islamic Azad University, North Tehran Branch, Iran \\ ${ }^{2}$ Farhangian University, Tehran, Iran \\ ${ }^{3}$ Department of Geology, Faculty of Earth Science, Shahid Beheshti University, Tehran, Iran \\ ${ }^{4}$ Department of Geology, Islamic Azad University, Zarand Branch, Iran \\ Email: *Sara.amanilari@yahoo.com, Iraj.Rasa17@gmail.com, Aliamiri731@yahoo.com
}

How to cite this paper: Lari, S.A., Rassa, I. and Amiri, A. (2017) Genetic Relationship of Minerals and Carbonate Units of Stratigraphy Sequence in the Ahmadabad Deposit (NE of Bafq) Using Data Related to Rare Earth Elements. Open Journal of Geology, 7, 1012-1021.

https://doi.org/10.4236/ojg.2017.77068

Received: April 8, 2017

Accepted: July 21, 2017

Published: July 24, 2017

Copyright $\odot 2017$ by authors and Scientific Research Publishing Inc. This work is licensed under the Creative Commons Attribution-NonCommercial International License (CC BY-NC 4.0). http://creativecommons.org/licenses/by-nc/4.0/ (c) (i) \& Open Access

\begin{abstract}
Ahmadabad $\mathrm{Pb}-\mathrm{Zn}$ ore deposit is located in the mineral area of Bahabad in Central Iran Zone. This ore deposit like other metallogenic areas in Bahabad is found in Triassic carbonate rocks. Carbonate rocks in Shotori formation have the highest frequency in the regional sequence stratigraphy. This formation is composed of TRSh1, TRSh2, TRSh3 and TRSh4 units. The TRSh3 unit hosts minerals in ore deposit Ahmadabad. Microcrystalline particles are the main constituent of these rocks. The most important minerals in this ore deposit include calamine Celestine, Cerussite and Wulfenite. The comparison of normalized ore patterns and carbonate sequence indicates that they have a specified genetic relationship. Here the TRSh2 unit is more similar to minerals.
\end{abstract}

\section{Keywords}

Ahmadabad Pb-Zn Ore Deposit, Carbonate Rocks Sequence, Rare Earth Elements

\section{Introduction}

Today, because of advances in the extraction of base metals from non-sulfide ores, these deposits have become particularly valuable and found an important economic status. Recently, much research has been done on them such as the research conducted by [1] [3]-[9] [11] [12]. The Pb-Zn ore deposit Ahmadabad, 
located at $80 \mathrm{~km}$ North-East in the metallogenic Bahabad belt belonging to the Central Iran structural zone, is considered one of the important ore deposits because of high abnormality of its Mo element (Figure 1). The ore deposits of the said belt are in the form of a straband Vein, Veinlet, Space Filling and Karst in the carbonate hosting rock [2]. The relative enrichment of the carbonate hosting rock compared to base metals and also limitation of mineralization to this lithology can raise the hypothesis of the relationship between ore deposits and carbonate hosting rocks. The aim of this study is finding the existence and/or non existence of any significant genetic relationship between ore minerals and carbonate rocks. To achieve this aim, normalized patterns of REEs were used.

\section{Study Methods}

Petrography and mineralogy studies of 30 thin-polished sections were performed in the geology laboratory of Tarbiyat Modarres University. To find out the existence of a genetic relationship, Rare Earth Elements related to 8 samples of host and non-host carbonate units and minerals were analyzed in ALS lab through ICP-MS technology. Findings were processed and then studied.

\section{Geology Setting}

Ahmadabad ore deposit was placed in Posht-e-Badam block in Central Iran Zone. Lithologically, the rocks of this zone were composed of dolomitic limestone sedimentary sequence, clastic and evaporative belonging to Triassic and Jurassic periods. Dolomitic limestone and dolomites of Shotori and Nayband Formations are the most important units in this zone and host minerals in Posht-e-Badam block. Therefore, the possible genetic relationship between these units and minerals are investigated in this paper.

\section{Lithology of Carbonates and Mineralogy}

Carbonates of the area consist of limestone, limestone-dolomite and dolomites

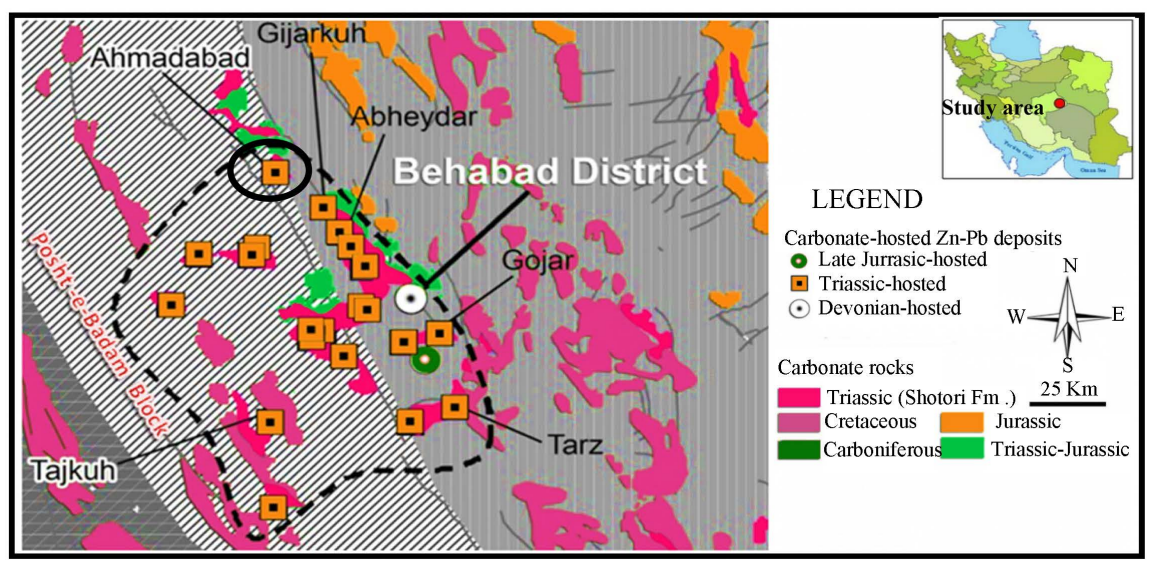

Figure 1. The position of ore deposit Ahmadabad among $\mathrm{Zn}-\mathrm{Pb}$ ore deposits of Triassic period in the metallogenic zone of Bahabad (adapted from [13] and relevant modifications). 
units of Shotori Formation (TRSh1-4) and the limestone unit belonging to Nayband Formation (TRnb2) (Figure 2(a)).

The TRSh1 unit is composed of thin, grey layers of dolomite limestone. Microcrystalline mud forms the highest volume of this rock. Fractures due to tectonic performance are filled with sparitic crystals (Figure 2(b)). The TRSh2 unit is the substrate of the mineral-hosting rock. This dolomite-limestone unit is made of an average to thick layer, ecru or cream in color, and has an inhomogeneous tissue; a microbial activity can also be seen in it (Figure 2(c)). Brown mass dolomites form the lithology of TRSh3 unit of mineral. The unit has a progressive edge with its lower and upper layers. In a thin scale, microcrystallines are the main constituents closely followed by sparitic crystals (Figure 2(d)). The TRSh4 is youngest carbonate unit of Shotori formation. The upper edge of this unit leads to gypsum-marl layers of Nayband Formation. Mesocratic microcrystallines constitute the central part which are seen in some areas in form of round
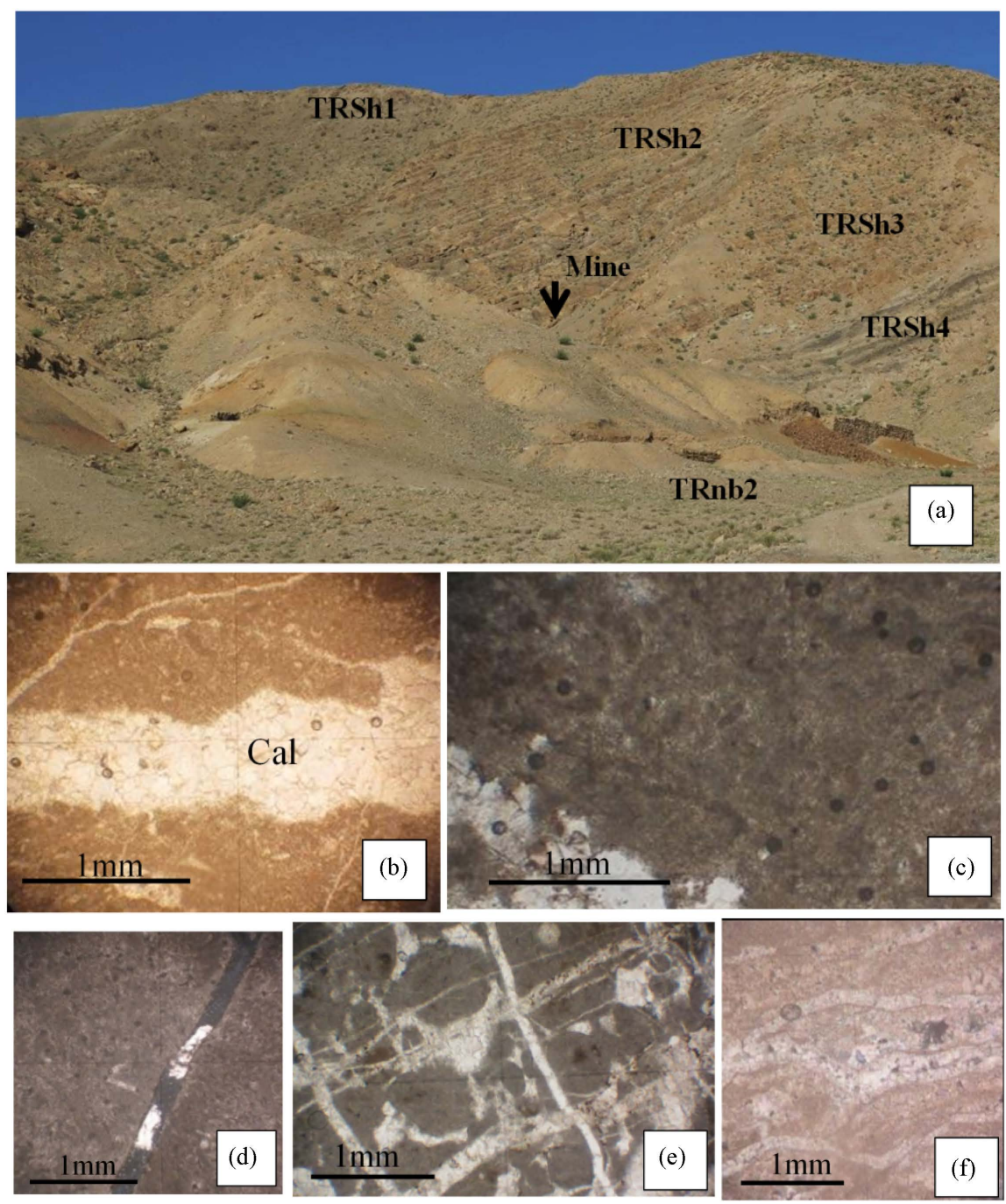

Figure 2. (a) General view of carbonate units in the area and the mine position in relation to them in Ahmadabad area Thin section of (b) TRSh1 unit; (c) TRSh2 unit; (d) TRSh3 unit and (f) TRSh4 unit. 
to oval ploids in different sizes. The unit, influenced by tectonic phases, has been severely fractured and filled by sparitic crystals (Figure 2(e)). The carbonate layer TRnb2 is cream in color and contains large quantities of brachia macrofossils. The sequence of dark and light layers is detectable in thin sections. The light parts are made of sparitics and the black parts are made of microcrystallines (Figure 2(f)).

$\mathrm{Pb}, \mathrm{Zn}, \mathrm{Sr}$ and Mo Non-sulfide minerals are the most important minerals of Ahmadabad mine ores made due to weathering and conversion of primary sulfide minerals. Examples of the latter include galena, sphalerite and pyrite which have been crushed due to tectonic phases leading to formation of non-sulfide minerals. Calamine minerals (Hemimorphite and Hydrozensite) (Figure 3(a)),
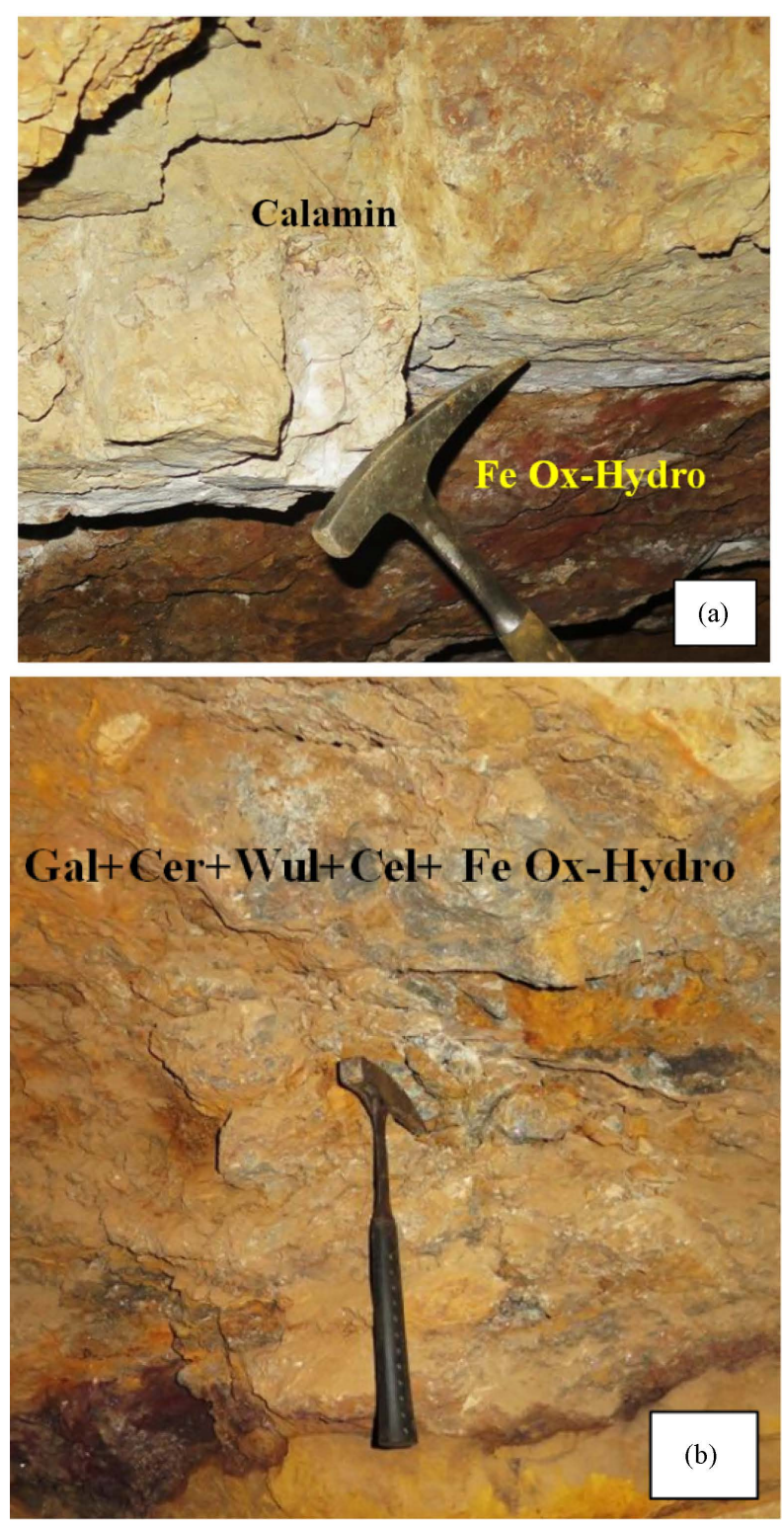

Figure 3. (a) Calamine non-sulfide mass ore deposit: Hydrozensite and Hemimorphite (Ore1) (b) Red non-sulfide mass ore deposit (Wulfenite-Cerussite-Celestine-Fe Oxide and Fe Hydroxide (Ore2) in Ahmadabad ore deposit. 
Celestine, Cerussite and I (Figure 3(b)) are the most important non-sulfide minerals of the ore deposit.

\section{Geochimestry}

\subsection{Geochimestry of Rare Earth Elements in Carbonate Units}

Samples of all carbonate units were normalized in relation to North American shale (NASC) [10], upper continental crust [14] and chondrite C1 [15]. The rare earth elements distribution diagram obtained in relation to North American shale and upper continental crust indicates depletion of all rare earth elements with respect to these two standards; so that all units in both distribution patterns are placed under axis 1 . This depletion for carbonate stratigraphic units takes place in the range of between $\frac{1}{5}$ to $\frac{1}{38}$ times the upper continental crust. The highest depletion belongs to ThSh2 unit and the lowest is related to TRnb2 unit. The average content of rare earth elements in minerals is $\frac{1}{83}$ times the upper continental crust. Samples of carbonate units in the area show the highest depletion compared to North American shale and this takes place in the range between $\frac{1}{6}$ to $\frac{1}{56}$ times the NASC. Figure 4 indicates that all samples of carbonate rocks have a uniform distribution pattern compared to North American shale and the upper continental crust. Also the depletion of light and rare earth elements is lower than that of heavy ones and all LREE patterns towards HREE show a downward trend. All samples have increased in relation to Eu and Tm elements and decreased with respect to $\mathrm{Yb}$. Among stratigraphic units of the area, the distribution pattern of rare earth elements in TRSh2 unit (substrate of the host layer) is the closest and the most similar to minerals. The same distribution trend can also be seen in the normalized pattern in relation to North American shale. Distribution of such elements, contrary to the two previous patterns, indicates an enrichment of LREE elements in carbonate units, so that all units except the TRSh2 unit are placed above 1. This enrichment in the TRSh2 unit includes only four elements ( $\mathrm{Pr}, \mathrm{Ce}, \mathrm{La}$, and $\mathrm{Nd}$ ). The normalized pattern in relation to chondrite indicates the decreasing trend of rare earth elements from LREE towards HREE in all units and mineral samples. The relation $\frac{L a}{Y b}$ reveals the rise and enrichment of light rare earth elements to heavy ones. This relation was separately calculated for carbonate units. The values obtained vary from 51 times in TRnb2 unit to 11 times in TRSh4 unit. The average value in carbonate units is equal to 14.24 (TRSh2: 12.5, TRSh1: 17.36, TRSh3: 15.94, TRSh4: 11.17 times); this shows the relative high enrichment of LREEs compared to HREEs. The ratio for minerals is $14 / 63$ in average and very close to average value of all carbonates.

Comparison of distribution patterns between minerals and rocks in the area represents undeniable similarities between these materials and carbonate rocks. 


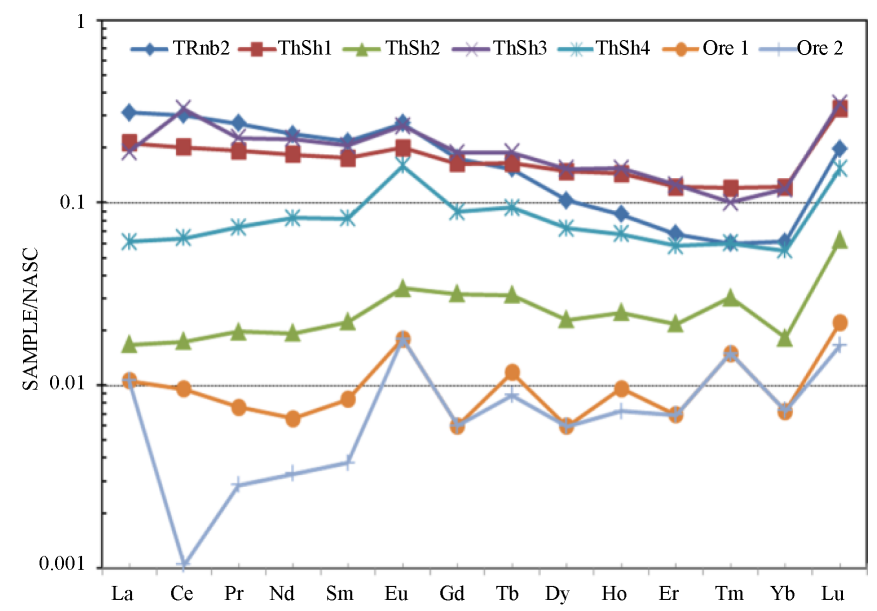

(a)

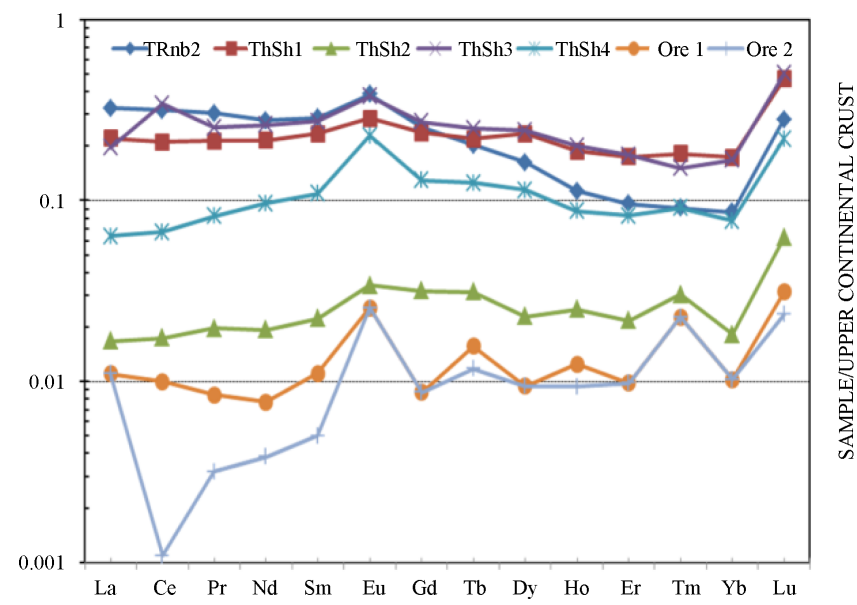

(b)

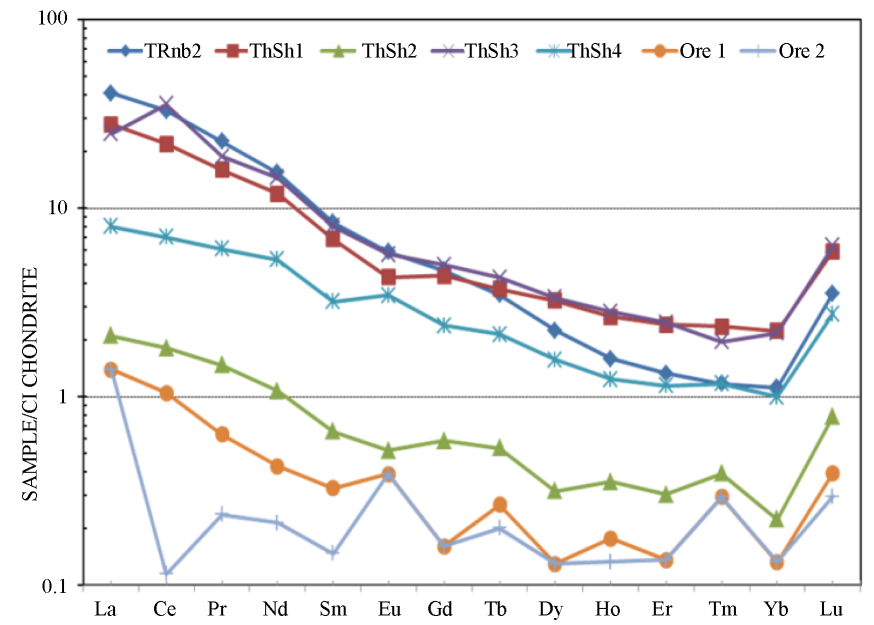

(c)

Figure 4. (a) Normalized pattern of rare earth elements of Ahmadabad carbonate units in relation to North American shale standard, (b) compared to upper continental crust and (c) compared to Chondrite C1.

Among these, the greatest similarity is related to TRSh2 limestone-dolomite which is the substrate of host unit (TRSh3) (Figure 4). 


\subsection{Comparison of Geochemistry of Rare Earth Elements in Ores and Carbonate Rocks}

After determining the genetic relationship of Ahmadabad ore deposit with carbonate units to better show this relationship, each carbonate unit was separately investigated with minerals. These units were normalized in relation to upper continental crust [14]. Ores (Ore1 \& Ore2)-TRSh1 unit (Figure 5(a)), Ores-

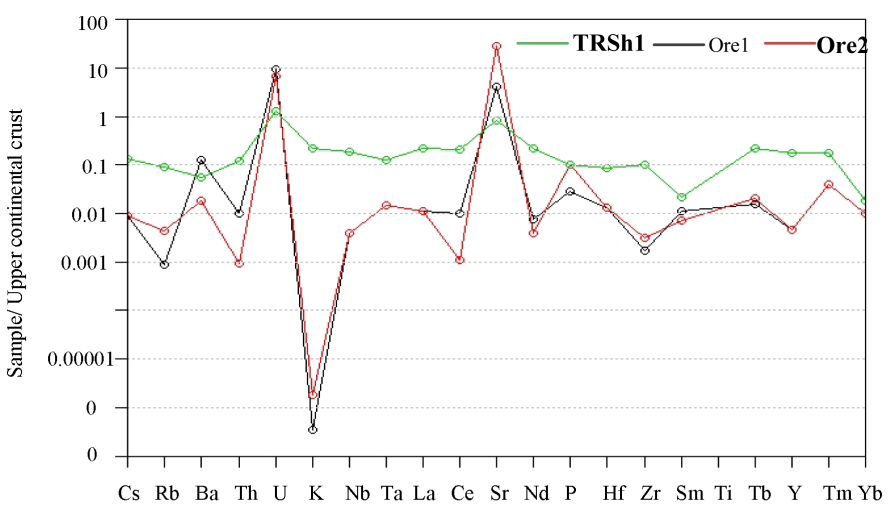

(a)

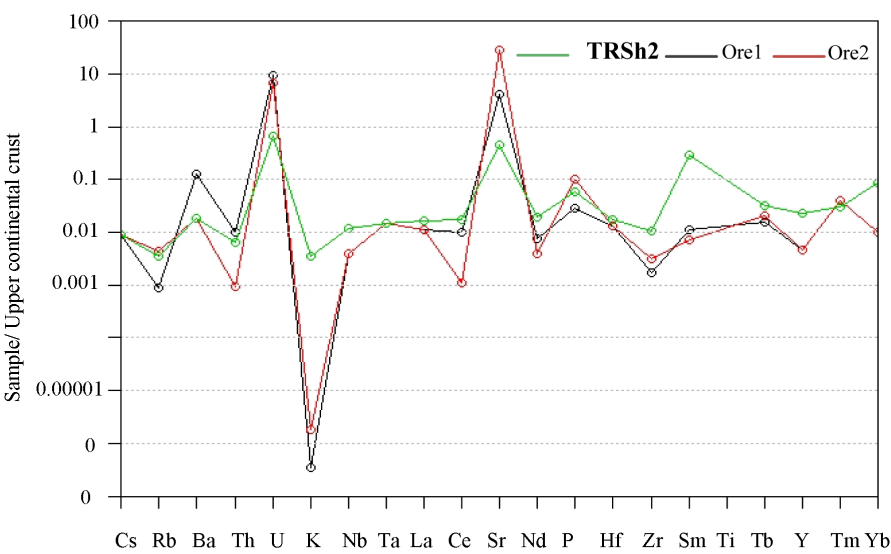

(b)

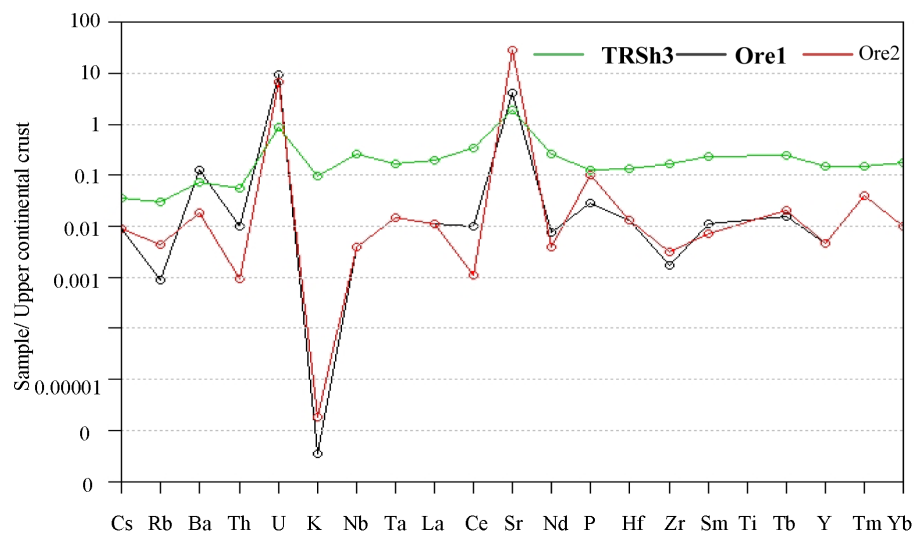

(c)

Figure 5. Comparison diagram of rare earth elements in $\mathrm{Zn}$-enriched ores (calamine) (ore1) and Pb-enriched ores (cerussite) (Ore2) with carbonate units; (a) TRSh1 unit; (b) TRSh2 unit C) TRSh3 unit. 
TRSh2 (Figure 5(b)), Ores-TRSh3 (Figure 5(c)), Ores-TRSh4 (Figure 6(a)) and Ores-TRSh4 (Figure 6(a)) and Ores-Ores-TRnb2 (Figure 6(b)). As diagrams indicate, mineral samples are very similar to all kinds of carbonate samples and the similarity of TRSh2 unit was the highest (Figure 5(b)). Diagrams (Figure 5 and Figure 6), show the significant decrease of potassium in comparison to carbonate rocks. This decrease corresponds to the amount of clay minerals in carbonate rocks and minerals. This reduction is clearly shown as a severe depletion of potassium in the diagrams relating to minerals.

\section{Conclusion}

Ahmadabad non-sulfide $\mathrm{Pb}-\mathrm{Zn}$ ore deposit belongs to metallogenic area Bahabad in the Central Itan structural zone. This mineralization is non-sulfide and the most important minerals include galena, sphalerite and pyrite that, after

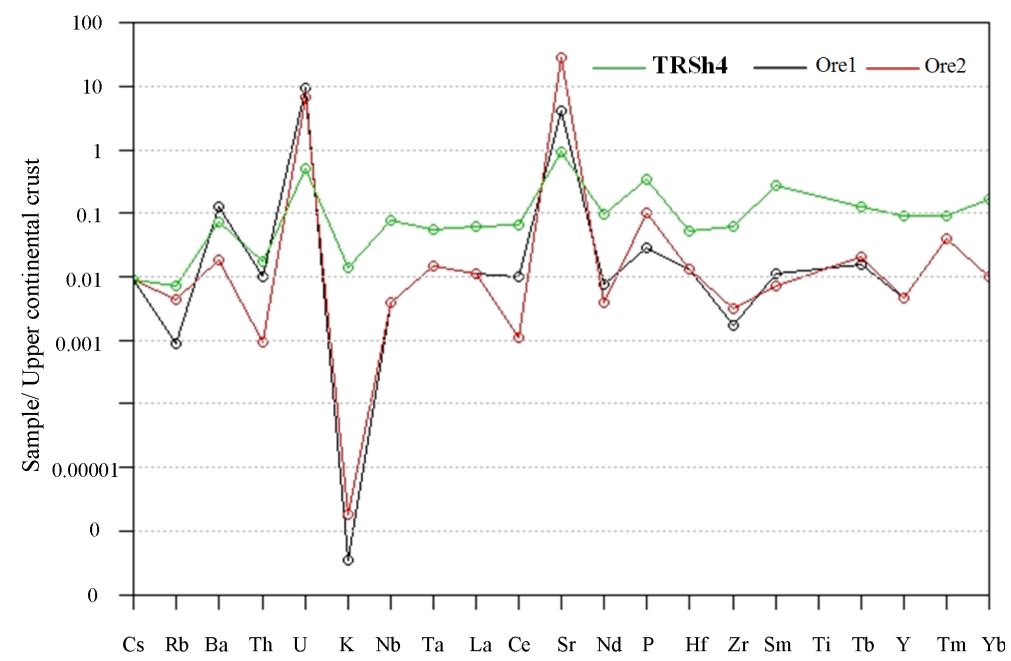

(a)

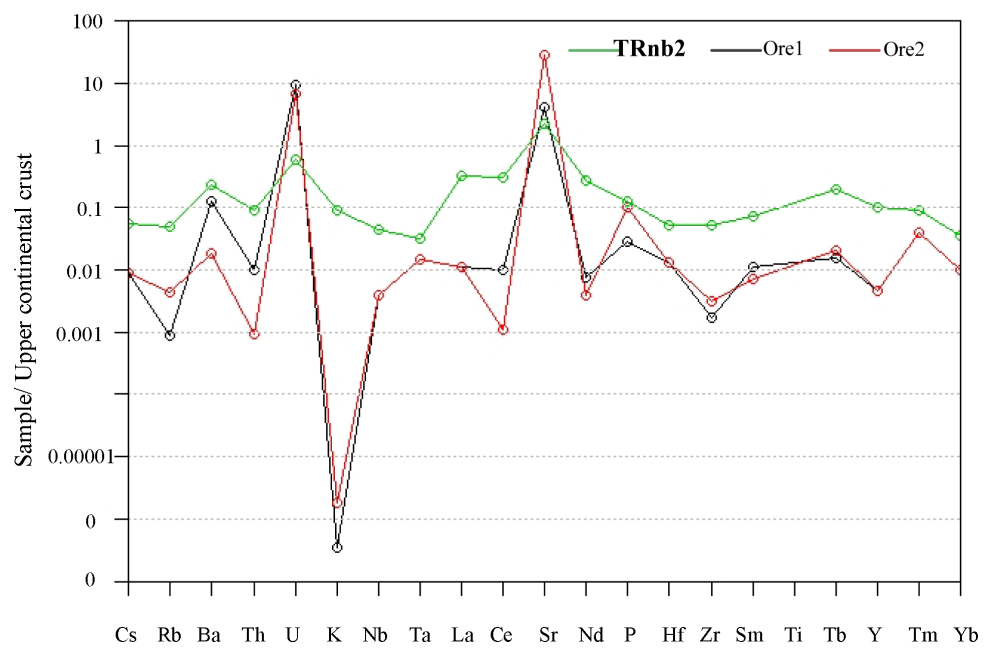

(b)

Figure 6. Comparison diagram of rare earth elements in $\mathrm{Zn}$-enriched ores (calamine) (ore1) and $\mathrm{Pb}$-enriched ores (cerussite) with carbonate units; (a) TRSh4 unit and (b) TRnb2 unit. 
supergene processes, have become non-sulfide $\mathrm{Pb}-\mathrm{Zn}$ minerals and Mo. The normalized patterns show that, with respect to distribution of rare earth elements, minerals are the most similar to TRSh2 unit among carbonate units. The results show that ore creating fluids and host rocks belong to a joint basin and all are formed under similar condition.

\section{Suggestions}

1) It is suggested to use SEM-EDS method to recognize the combination of carbonates types in ore deposit. Through this method, it is possible to examine amount of replacement of $\mathrm{ZnO}$ in carbonate rocks. Besides showing different types of carbonate rocks, the current results can determine effects of metal-rich fluids on these rocks.

2) In order to accurately determine of minerals types used QPA method.

\section{References}

[1] Ahn, H.I. (2010) Mineralogyand Geochemistry of the Non-Sufide Zn Deposits in the Sierra Mojada District, Coahailo, Mexico. Published Thesis, University of Texas at Austin, $179 \mathrm{p}$.

[2] Amiri, A., Rassa, I., Khakzad, A. and Adabi, M.H. (2009) Thermometry and Formation Model of Carbonate-Hosted Zn-Pb Sulfide Deposits in the Ravar-bafgh Area Based on Sulfur Stable Isotopes. Scientific Quarterly Journal, GEOSCIENCES, 18, 3-10.

[3] Boni, M., Aversa, G., Balassone, G. and Gilg, H.A. (2003) The Zn-Pb Ore Deposits SW Sardinia (Italy): From Sulfides to "Calamine". In: Andrew, C., Ashton, J., Bolandm., Earls, G., Fusciardi, L., Kelly, J. and Stanly, G., Eds., The Geology and Genesis of Europ's Major Base Metal Deposits, Irish Association for Economic Geology, 283-291.

[4] Boni, M. (2005) The Geology and Mineralogy of Nonsulfide Zinc Deposits. LEAD and ZINC'05, Kyoto, 17-19 October 2005, 1299-1314.

[5] Boni, M., Mondillo, N. and Balassone, G. (2011) Zincian Dolomite: A Perculiar Dedolomitization Case? Geology, 39, 183-186. https://doi.org/10.1130/G31486.1

[6] Gilg, H.A. (2000) D-H Evidence for the Timing of Kaolinization in Northeast Bavaria, Germany. Chemical Geology, 170, 5-18.

https://doi.org/10.1016/S0009-2541(99)00239-9

[7] Gilg, H.A. and Boni, M. (2004) stable Isotope Composition of on $\mathrm{Zn}$ and $\mathrm{Pb} \mathrm{Car}-$ bonates; Their Role in Exploration of Non-Sulphide Ores. In: Boni, M., Ed., Publication-Geology Department and Extension Service, University of Western Australia, Australia, University of Western Australia, Geology Department and Extension Service: Perth, Eest. Aust., Australia, 361-365.

[8] Gilg, H.A., Boni, M., Balassone, G., Cameron, R., Banks, A.D. and Moore, F. (2005) Marble-Hosted Sulfide Ores in the Angouran Zn-(Pb-Ag) Deposit, NW Iran: Interaction of Sedimentary Brines with a Metamorphic Core Complex, Mineral Deposit.

[9] Gilg, H.A., Boni, M., Hochleitner, R. and Struck, U. (2008) Stable Isotope Geochemistry of Carbonate Minerals in Supergene Oxidation Zones of $\mathrm{Zn}-\mathrm{Pb}$ Deposits. Ore Geology Reviews, 33, 117-133. https://doi.org/10.1016/j.oregeorev.2007.02.005

[10] Gromet, L.P., Dymek, R.F., Haskin, L.A. and Korotev, R.L. (1984) The "North American Shale Composite": Its Compilation, Major and Trace Element Characteristics. Geochimica et Cosmochimica Acta, 48, 2469-2482. 
https://doi.org/10.1016/0016-7037(84)90298-9

[11] Large, D. (2001) The Geology of Non-Sulfide Zinc Deposits-An Overview. Erzmetall, 54, 264-276.

[12] Mondillo, N. (2014) Supergen Nonsulfide Zinc-Lead Deposits: The Examples of Jaballi (Yaman) and Yanque (Peru). Doctoral Thesis in Economic Geology, University Digital Studi di Napoel “FEDRICII”, School in Earth Science, 185 p.

[13] Rajabi, A., Rastad, E. and Canet, C. (2013) Metallogeny of Permian-Trassic Carbonate-Hosted $\mathrm{Zn}-\mathrm{Pb}$ and F Deposits of Iran: Areview for Future Mineral Exploration, Australian Geoscience Journal, No. 60, 197-216.

[14] Sun, S.S. and McDonough, W.F. (1989) Chemical and Isotopic Systematics of Oceanic Basalts: Implications for Mantle Composition and Processes. In: Saunders, A.D. and Norry, M.J., Eds., Magmatism in Ocean Basins, GeolSoclond Spec Pub 42, 313-345.

[15] Taylor, S.R. and Mc Lennan, S.M. (1981) The Composition and Evolution of the Continental Crust: Rare Earth Element Evidence from Sedimentary Rocks. Philosophical Transactions of the Royal Society A, 301, 381-399.

https://doi.org/10.1098/rsta.1981.0119

Submit or recommend next manuscript to SCIRP and we will provide best service for you:

Accepting pre-submission inquiries through Email, Facebook, LinkedIn, Twitter, etc. A wide selection of journals (inclusive of 9 subjects, more than 200 journals)

Providing 24-hour high-quality service

User-friendly online submission system

Fair and swift peer-review system

Efficient typesetting and proofreading procedure

Display of the result of downloads and visits, as well as the number of cited articles

Maximum dissemination of your research work

Submit your manuscript at: http://papersubmission.scirp.org/

Or contact ojg@scirp.org 